\title{
Twins and Transsexualism: An Update and a Preview; Research Reviews: Conjoined Twins, Angiographic Lesions, Single Versus Double Embryo Transfer; Headlines: School Placement Legislation, Junior Taekwondo Olympics, Prosthetic Ears, Murder Victim
}

\author{
Nancy L. Segal \\ Department of Psychology, California State University, Fullerton, United States of America
}

\begin{abstract}
In recent years, there has been growing appreciation for the complexity of gender identity. Focusing on monozygotic (MZ) twins discordant for transsexualism can offer clues to events that may trigger this behavioral difference, offering new information about critical underlying factors. An update of twin research in this area is provided, together with a preview of a compelling new film, 'Red Without Blue.' Next, twin study findings on the topics of conjoined twinning, angiographic lesions and embryo transfer are provided. This is followed by a survey of newsworthy twins and twin-related events.
\end{abstract}

\section{Twins and Transsexualism: An Update and a Preview}

Most people experience correspondence between their sexual anatomy and gender identity. Individuals born with one $\mathrm{X}$ chromosome and one $\mathrm{Y}$ chromosome typically identify as males, while individuals born with two $\mathrm{X}$ chromosomes typically identify as females. This is because the different chromosomal arrangements trigger sex-specific hormones (both prenatally and during development) that either masculinize or feminize certain brain regions. However, in rare cases these processes do not proceed as planned. Approximately 1/30,000 males and $1 / 100,000$ females believe that they were born into the wrong bodies (Michel et al., 2001). Their feeling of belonging to the other sex may be so intense that they seek surgical reassignment and hormonal treatment to align their body with their mind.
In recent years, there has been growing appreciation for the complexity of gender identity. It is known that the pathways from the genes we inherit to the gender we embrace are not deterministic or direct. There is increasing evidence of early biological influences on gender identification, for example, a tiny brain region called the bed nucleus of the stria terminalis (BSTc) is smaller in male-to-female (MTF) transsexuals than in heterosexual males (Zhou et al., 1995). It was later determined that this difference is explained by the smaller number of somatostatin neurons in MTFs, similar to that of females (Kruijver et al., 2000; somatostatin is a growthinhibiting hormone.) Physical measures, such as the body mass index (BMI) and waist-to-hip ratio, are higher among female-to-male (FTM) transsexuals than heterosexual females
(Bosinski et al., 1997). An increased frequency of polycystic ovarian disease (PCOD) and elevated androgen levels have been found among FTM transsexuals (Futterweit et al., 1986; Bosinski et al., 1997), also consistent with biological underpinnings. Above all, feelings of being born into the wrong sex emerge so early (often before age 5) that it is difficult to assign causal roles to rearing or experience. That is not to say that early life events are insignificant - only that they may reflect, rather than decide, how gender identity develops. Why would parents of same-sex twins

Address for correspondence: Nancy L. Segal, Department of Psychology, California State University, Fullerton, CA 92834, USA. E-mail: nsegal@fullerton.edu 
choose to raise one twin as a male and the other as a female?

Genes are not the sole determinants of behavior, helping us understand why $\mathrm{MZ}$ twins, who share $100 \%$ of their genes, do not match across all measured traits. In fact, $\mathrm{MZ}$ twins do not show perfect concordance in any characteristic (although they are more alike than any other pair of relatives). The fact that $\mathrm{MZ}$ cotwins can show within-pair variation means that nongenetic factors affect all phases of development. Gender identity is no exception - although only nine $M Z$ female twin pairs with one FTM member have been cited in the scientific literature. MTF transsexual twin pairs are slightly more common; approximately twelve pairs have been identified (see Segal, 2006).

Even though MZ twins can differ so profoundly and fundamentally in one way, they do not necessarily differ in all ways. My two in-depth case studies and interviews with several transsexual MZ pairs show that the twins still share many personality traits and interests, even though one twin changed sex (Segal, 2005; 2006). Most $\mathrm{MZ}$ twins also maintain close, supportive relationships with one another, despite disapproval and rejection by family members in some cases.

Studying MZ twins discordant for gender identity and transsexualism offers clues to factors that may trigger their difference. This information is vital to parents raising young children wishing to 'magically change' into the opposite sex. Parents may blame them- selves unnecessarily for their child's behavior, and/or try to resist or reshape their child's inclinations. As such, focusing on $\mathrm{MZ}$ twins can be informative, but also reassuring because the factors affecting gender development were most likely at work before the twins were born.

I recently had the opportunity to personally meet and interview $\mathrm{MZ}$ twins, Mark Oliver and Clair Joy. I met Mark about a year ago (over the telephone) during taping of an interview for a film about the twins' lives; see below. The twins were born as Mark Oliver and Alexander (Alex) Joy in March 1983, in Missoula, Montana. The slim blonde boys were so identical that even their parents confused them. Their mother, Jenny, decided to paint Mark's toenail red and Alex's toenail blue, and to dress them in outfits that were identical but in contrasting colors (red and blue). They are a rare pair Mark is homosexual and Clair recently underwent sex reassignment surgery to become a female.

'Mom liked us feminine,' recalled one of the twins. Jenny also enlisted her young sons as 'hosts' for parties that she organized for her female friends. She had the 5-year-old twins prepare cheese squares and fruit slices, and allowed them to interact with her guests. At about this time, Jenny asked their kindergarten teacher if she thought her sons were gay, but the reply was 'no, they are sweet and masculine'.' Years later, the teacher was amazed to learn the truth.
When the twins were 9-years-old, they felt attracted to other boys in their class. They would excitedly discuss these other children and decide which twin would telephone them - it was an important decision. At about this time, Clair recalls staring at herself in front of the mirror for hours while she hid her genitals. 'I liked this image of myself,' she said, 'but I didn't know why.'

Today, Mark lives and works as an artist in San Francisco. He is in a longterm relationship with another young man. In October 2006, Alex underwent hormone therapy and sex reassignment surgery to become a female named Clair. She lives and works as a counselor at the Dimensions Clinic, in San Francisco, providing support to individuals who are transsexual, gay, lesbian, bisexual and intersex. The twins are currently promoting their 2007 film, 'Red Without Blue,' a moving expose of what happens to families and twins when one twin transitions (Daniels, 2007).

'Red Without Blue,' produced by Brooke Sebold from San Francisco, includes candid interviews with family members and footage of the twins as children and adults. I have seen the film and recommend it for individuals with interests in twins and gender identity. A website (www.redwithoutblue.com) provides additional information about this award-winning film. Twins in concordant or discordant pairs are invited to contact Dr Nancy Segal (nsegal@fullerton.edu) to participate in a gender identity study.

\section{Research Reviews: Conjoined Twins, Angiographic Lesions, Single Versus Double Embryo Transfer}

\section{$\overline{\text { Conjoined Twins }}$}

A recent paper by Kokcu, Cetinkaya, Aydin, \& Tosun (2007) is described as a case report of a rare pair of conjoined male cephalothoracoomphalopagus twins, but it is far more comprehensive. The work provides an extensive historical perspective, classification scheme, and discussion of the incidence, etiol-
\end{abstract}

ogy, and management of conjoined twin pairs. Readers learn about 3000year-old Mexican clay sculptures of facial and cranial duplication, and a pair of conjoined Hungarian twin sisters who toured Europe in the 18th century. Cross-cultural frequencies of conjoined twinning are compared: 1:14,000 live births in India and
Africa, and 1:250,000 births in the United State and Europe. The frequencies and characteristics of the different conjoined twin types are also provided, ranging from the most common (thoracopagus: 19\%; fusing from the head to the umbilicus) to the least common (rachiopagus: 3\%; fused above the sacrum). 
Processes responsible for conjoined twinning are unresolved, but several classes of explanation have been proposed. The two most common theories are incomplete zygotic fission, and the fusion of two monozygotic (MZ) or dizygotic (DZ) embryos early in development; however, data are consistent with conjoined twins being MZ. Some researchers have proposed that the proximity of an ovum and first polar body (after fertilization by separate sperm) might cause parasitic opposite-sex conjoined twinning. An association with $\mathrm{X}$-chromosome inactivation has also been suggested, but has not been demonstrated.

The case study appended to this paper concerns the first known pair of male cephalothoracoomphalopagus twins. The twins were joined from the head to the umbilicus. Present were one head and neck, a single thorax, a single upper abdomen and a single umbilical cord. The mother was a 27-year-old multigravida whose first pregnancy ended in fetal death at 23 weeks; subsequently, she had two normal pregnancies. Conjoined twins were diagnosed at the 34 th week of her fourth pregnancy; prior to that, she had not received prenatal care. Exposure to teratogens as a possible cause of conjoined twinning was ruled out. The investigators urge careful documentation of all conjoined twin cases, given the information that is potentially retrievable from each rare case.

\section{$\overline{\text { Angiographic Lesions. }}$}

A case study by Gullu, Kizzilay, Ates, \& Akcar (2007), reporting concordance for angiographic lesions and post-operative outcomes in 62-yearold MZ male co-twins, is important and timely. The extent to which the development of angiographic lesions is explained by genetic and/or environmental factors has been a matter of debate among physicians. The male twins in this case showed similar artheroslerotic lesions, despite differing significantly for coronary risk factors, underlining a contribution from genetic factors.

Unfortunately, the investigators failed to document the method by which the zygosity (twin type) of this twin pair was established. If the pair in question proved to be DZ, this would greatly alter the data interpretation. Furthermore, other researchers would hesitate to use this pair in pooled analyses. Gullu et al. will, hopefully, provide this information in a subsequent note.

\section{Single Versus Double Embryo Transfer}

A current trend in artificial reproductive technology is the transfer of single embryos, rather than several embryos, to avoid high-risk multiple pregnancies. However, Danish investigators have demonstrated that infertile couples prefer the transfer of two embryos, knowing that this could lead to twins (Hojgaard, Ottosen, Kesmodel, \& Ingerslev, 2007). A questionnaire survey of 414 women and 404 men indicated that the majority favored having twins $(57.8 \%)$ as compared with having a singleton (37.9\%). Justification for these responses were a desire for their children to have siblings, a favorable view of twinship and a wish to reduce the number of in vitro fertilization treatments.

Note: The desire for twins appears to extend beyond the population studied by Hojgaard et al. In studies of virtual twins (same-age unrelated siblings) and adopted Chinese twins, many parents requested twins from their adoption agencies and organizations. It would seem that some of the same reasons given by parents in the Danish study would apply to these adoptive families, as well.

\section{Headlines: School Placement Legislation, Junior Taekwondo Olympics, Prosthetic Ears, Murder Victim}

\section{School Placement Legislation}

Senate Bill 78 was signed into law on July 30, 2007 by New Hampshire Governor John Lynch (Dolan, 2007, personal communication). This bill grants New Hampshire parents of multiples a significant voice in the classroom placement of their twin children (same or separate classes). At the present time, four states have passed a bill, ten states have sponsored a bill, two states have passed a resolution allowing parental input and fourteen states are awaiting sponsorship of a bill. Additional information and related resources on twins' school legislation are available at www. twinslaw.com; also see related articles in Twin Research and Human Genetics (Segal, 2005, 2006).

\section{Junior Taekwondo Olympics}

Thirteen-year-old identical twins, Joseph and Michael Dane from Chester Springs, Pennsylvania distinguished themselves in the 2007 United States Taekwondo Junior Olympics: Joseph defeated his twin brother 12 to 9 in the final round of competition (Sports Illustrated, 2007). The fact that identical co-twins achieved the same high level of skill at the national level underlines genetic contributions to physical interests and skill. If these particular twins follow this pattern consistently, this would suggest that small differences in physical ability, motivation, training and/or stamina might make a big difference in their competitive outcomes. Alternatively, if the twins show reversals in who outperforms whom, then unknown factors on a given day may be more decisive. The relative athletic performances of these identical twins, and others, have clear implications for how we understand the bases of physical skills. It will be fascinating to follow the progress of these twins as they continue to compete. 


\section{Prosthetic Ears}

Five-year-old Jorden and Jaden Flowers, the fraternal twin children of Olympic bobsled champion, Vonetta Flowers, have attracted recent medical and public interest (Libraries: Medical News, 2007). Jorden was born with bilateral microtia, a condition involving either the absence or partial presence of the outer ear on both sides of the head. This condition is estimated to occur in $1 / 25,000$ births. Jorden's twin brother, Jaden, is unaffected. The condition was detected at birth, but it was not until Jorden was 18-months-old that doctors determined he was not receiving sound. The twins were born 10 weeks prematurely and weighed less than 3 pounds.

Jorden underwent auditory brain transplant surgery in which electrodes were inserted into the brain region responsible for processing sound. An external processor, placed behind his ear, picks up sounds. However, it was in September 2007 that Jorden made history by becoming the youngest patient to acquire a set of prosthetic ears. The ears were cast from those of his twin brother and colored to match Jorden's skin tone. He now looks no different from other children, an enormous advantage given that he is beginning school. The ears were crafted by Maxillofacial Prosthetic Services, directed by Dr Glenn Turner, at the University of Alabama, Birmingham.

\section{Murder Victim}

On the morning of July 30, 2007, I received several telephone calls from Canadian journalists. A 27-year-old twin, Jason R. Weismiller, had been charged with the second-degree murder of his twin brother (Ligaya, 2007). The twins appeared to be identical. Questions posed by the media mostly concerned (1) whether this was the first such case of a co-twin killing, and (2) possible links between twinship and murder.

There has, in fact, been a previous case involving the murder of an identical male twin by his twin brother. In
1991, Jeff Henry from rural Georgia shot and murdered his twin brother Greg at the age of 36 . The twins have been described as polar opposites - a 'saint' and a 'sinner' — but 'inseparable' (Glatt, 1999). The murder followed a long afternoon of drinking and an argument over Jeff's new theory about power. More recently, in 1996 a murder plot conceived by 22year-old identical twin, Jeen Han, of southern California, attracted worldwide attention. Jeen had hoped to steal her sister Sunny's identity in order to restore her own reputation; Jeen had been charged with stealing credit cards and with other illegal activities. (Interestingly, Sunny had engaged in similar pursuits, but to a lesser extent.) The plot ultimately failed and the twin sisters became close again (Segal, 2000).

\section{References}

Bosinski, H. A. G., Schroeder, I., Peter, M., Arndt, R., Wille, R., \& Sippell, W. G. (1997). Anthropometrical measurements and androgen levels in males, females, and hormonally untreated female-to-male transsexuals. Archives of Sexual Behavior, 26, 143-157.

Daniels, C. (July 13, 2007). All in This Together. Los Angeles Times, p. E16.

Dolan, K. (July 31, 2007). Personal communication.

Futterweit, W., Weiss, R. A., \& Fagerstrom, R. M. (1986). Endocrine evaluation of forty female-to-male transsexuals: Increased frequency of polycystic ovarian disease in female transsexualism. Archives of Sexual Behavior, 15, 69-78.

Glatt, J. (1999). Evil twins. New York: St. Martin's Press.

Gullu, A.U., Kizzilay, M., Ates, M., \& Akcar, M. (2007). The comparison of angiographic lesions and clinical outcomes in identical twins. Cardiovascular and Thoracic Surgery, 6, 575-576.

Hojgaard, A., Ottosen, L. D. M., Kesmodel, U., \& Ingerslev, H. J. (2007). Patient attitudes towards twin pregnancies and single embryo transfer: A questionnaire study. Human
Reproduction, doi:10,1093/humrep/ dem 173 .

Kokcu, A., Cetinkaya, M. B., Aydin, O., \& Tosun, M. (2007). Conjoined twins: Historical perspective and report of a case. Journal of MaternalFetal and Neonatal Medicine, 20, 349-356.

Kruijver, F. P. M., Zhou, J.-N., Pool, C.W., Hofman, M. A., Gooren, L. J. G., \& Swaab, D. F. (2000). Male-to-female transsexuals have female neuron numbers in a limbic nucleus. Journal of Clinical Endocrinology and Metabolism, 85, 2034-2041.

Libraries: Medical News (September 5, 2007). Experts Fashion Prosthetic Ears for Young Son of Olympic Medalist. Medical News, University of Florida Health Science Center.

Ligaya, A. (July 31, 2007). Surrey man charged in death of twin brother. Globe andmail.com/servlet/story/LAC.200707 31.Bcbriefs31-1/TPStory/National.

Michel, A., Mormont, C., \& Legros, J. J. (2001). A psycho-endocrinological overview of transsexualism. European Journal of Endocrinology, 145, 365-376.

Segal, N. L. (2000). Entwined lives: Twins and what they tell us about human behavior. New York: Plume.

Segal, N. L. (2005). Education issues. Twin Research \& Human Genetics, 8, 409-414.

Segal, N. L. (2005). Indivisible by two: Lives of extraordinary twins. Cambridge, MA: Harvard University Press.

Segal, N. L. (2006). Female to male: Two monozygotic twin pairs discordant for transsexualism. Archives of Sexual Behavior, 35, 347-358.

Segal, N. L. (2006). Same or separate classrooms: A twin bill. Twin Research and Human Genetics, 9, 473-478.

Sports Illustrated (September 3, 2007). 'Faces in the Crowd: Joseph and Michael Dane.' Sports Illustrated, p. 44.

Zhou, J., Hofman, M. A., Gooren, L. J. G., \& Swaab, D. F. (1995). A sex difference in the human brain and its relation to transsexuality. Nature, 378, 68-70. 